\title{
Biosemiotics, Bioinformatics, and Responsibility: Ambivalent Consequences of the Deciphering of the Human Genome for Society and Science
}

\author{
Klaus Fuchs-Kittowski, Hans-Alfred Rosenthal
}

Prof. Dr. Klaus Fuchs-Kittowski

Fachhochschule für Technik und Wirtschaft Berlin

Studiengang Betriebliche Umweltinformatik

Ostendstraße 25, D-12459 Berlin

e-mail:fuchs@cs.tu-berlin.de

Prof. Dr. Hans A. Rosenthal, Institut für Virologie, Charité,

Humboldt-Universität Berlin, D-10117

e-mail: h.a.rosenthal@Online.de

\begin{abstract}
Deciphering the Human Genome is one of the greatest achievements of modern science. The genetic code shows the importance of semiotics in our understanding of evolution. Biosemiotics as the study of signs, communication and information in living organisms has very much in common with Bioinformatics. Biology, Bioinformatics, and Biosemiotics meet, but with ambivalent effects on science and society. In the paper we discuss the scientific and social implications, as well as a number of ethical problems. For instance, does the fertilized egg have the right to human dignity? Should pre-implantation diagnostics remain absolutely prohibited in the German society, while abortion of a
\end{abstract}

\begin{abstract}
twelve-week old fetus after counseling is allowed? What are the genetically engineered interventions that make sense from the few point of medicine, and what are those that should be fundamentally rejected? Furthermore, the possibility is being discussed that the human genome project and the considerations accompanying it may eventually initiate new varieties of eugenics and racism (Fuchs-Kittowski, Rosenthal, Rosenthal 2005).
\end{abstract}

Keywords: Human genome, genetic code, genetic determinism, information generation, Biosemiotics, Bioinformatics, human dignity, eugenics, racism

1 Synergy effect: Biology, Bioinformatics, and Biosemiotics meet - an interdisciplinary research field

Clearly, Bioinformatics and Biosemiotics meet and create an interdisciplinary research field in accordance with the definition of "interdisciplinary" (Parthey 1983). The possibilities of the young interdisciplinary science of bioinformatics/biosemiotics have to be activated, risks have to be removed, and the human rights have to be protected while respecting human dignity. The recent scientific development $r$, equires an assessment of the ambivalent effects and ethical consequences of all of this. Bioscientific research facilities as well as biotech enterprises face the extensively and eventually lengthy research task to infer the causes of disease from the data of sequencing of DNA generated from healthy and ill persons, respectively, and in particular from the data of gene activities. The aim is to achieve the early recognition and possible prophylaxes with regard to diseases which are not at all treatable so far or treatable only with little success. In 
doing this bioinformatics plays a decisive role. This field includes the know-how concerning several innovative technologies that are based on results of pure and applied research and also stimulate further research. Now, after the successful deciphering of the human genome, the transfer of knowledge into marketing-able medications as well as methods of early recognition remains to be developed. It is in this manner that molecular bioinformatics as an interdisciplinary research field has an actual impact on the development of economy and finance, and is therefore a special and revolutionary moment of the present development of science which we have to analyze.

The deciphering of the human genome is one of the greatest achievements of modern science in our days. Efficient research teams in the USA, Great Britain, France, Japan and Germany were involved in it (see figure 1).

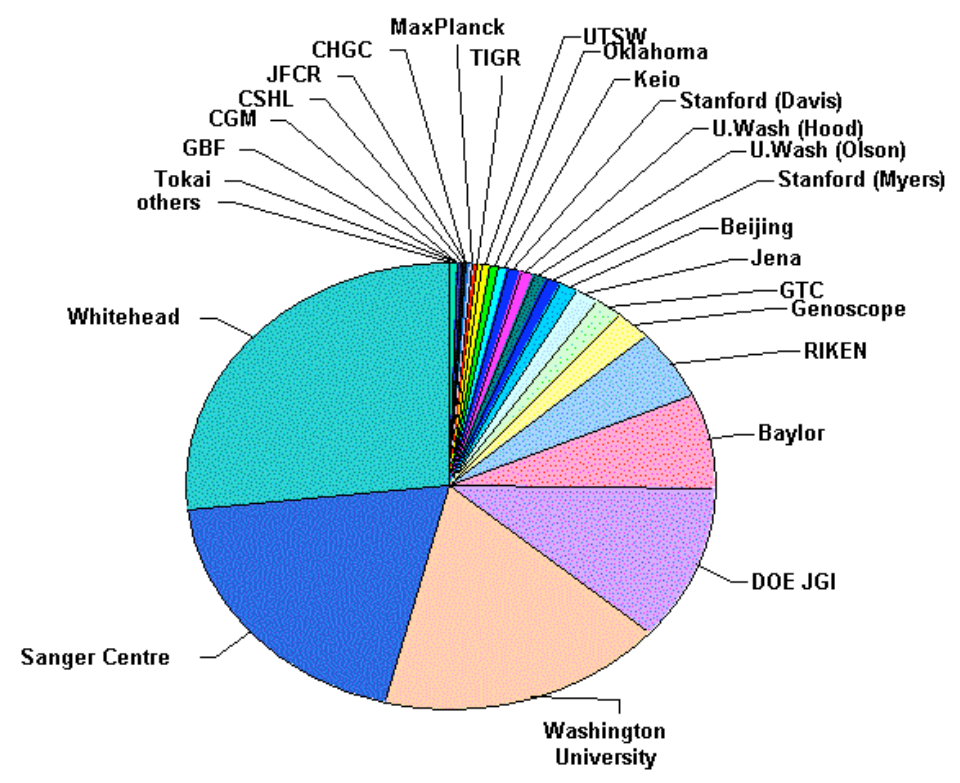

Figure 1

One result of the "Human Genome Project", namely that humans do not possess much more genes than the earthworm, is placed into one line with the so called "great insults of humans" by modern science. Indeed, as the other great discoveries, this shows nothing else than that humans are a part of nature. And as such they are social beings. Finding out that the number of human genes is about 30.000 and not, as assumed so far, about 150.000, was communicated by Andrè Rosenthal (The International Human Genome Sequencing Consortium 2001) ${ }^{1}$.

By the first two theses of the mentioned joint paper we do approach important epistemological and methodological problems of modern biology. We will add here our view of the importance of a biosemiotic view to solve some of the epistemological and methodological problems in this field. This position is aimed at a new understanding of information through a theory of complex, evolutionary systems (Fuchs, Hofkirchner 2002) and a specific understanding of information as a triad: of form (syntax), content (semantics), and effect (pragmatics) (Fuchs-Kittowski 1998). In the living realm, in the process of information generation these are process stages that are mutually conditioning one another.

\footnotetext{
${ }^{1}$ André Rosenthal spoke about this at the Cold Spring Harbour Symposium on Genome Sequencing and Biology on May the 12th, 2000 , and it was concern of a publication in Nature 405, 311 of the International Consortium, for which André Rosenthal has coordinated the German Contribution.
} 


\section{The Limits of Laplace's Demon}

The point is that even the so called "Demon of Laplace" is not able, to explain the life of a single cell or a multicellular organism by means of molecular processes alone. This is due to an uncertainty relation in the molecular processes, so that they are not in accordance with mechanistic conceptions. Essentially, the replication of the DNA is exact as well as imperfect. In fact, this dualism, this complementarity of constancy and variability, is what brings life forward, what triggers evolution. It is imperfectness or inexactness what is relevant after all, a kind of uncertainty in the molecular field of enzymatic processes. It is here where the DNA polymerase for instance makes errors. The frequency of mistakes depends on particular mutations in the polymerase gene. In general, it may be said: There is no polymerase without errors. There is no evolution without errors in the replication of the DNA - no life without this molecular uncertainty. According to this, a deep dialectics of chance and necessity as well as a complementarity of constancy and variability resulting there from, are crucial. In a quickly changing environment, organisms with a higher error frequency gain an advantage. Mostly, very large error frequencies are not compatible with life. On the other hand, an absence of errors would prevent the evolutionary process in the first place. Life is connected with this biochemical uncertainty, this tightrope walk between constancy and variability.

Of course, the concepts "uncertainty" and "complementarity" within the biological process are used in a figurative or generalized sense only in order to characterize an analogous epistemological situation as we encounter it in the atomic and subatomic fields of physics (wave-particle dualism). Today, in the discussion of neurophysiologists on brain structure and free will, this idea of a generalized complementarity, originally developed by Niels Bohr, might probably be helpful, too. This epistemological experience of modern physics, in particular the generalized principle of complementarity, should also be applied to analogous epistemological situations in other fields of science. In computer science as well as in Bioinformatics, we can, or have to, speak of complementarity: in human (semantic) as well as machine (syntactic) information processing, with respect to the technical and social aspects of computer science.

According to our viewpoint, the principle of "generalized complementarity" in the sense of Niels Bohr (1933), understood as a description of dialectical events, may be fertile for developing models and theories in other fields of science, in situations that are similar to that of quantum physics. So first of all, the principle of information generation proves as fundamental in model and theory development in the border region among physics, chemistry, and biology, in order to understand the origin of life (Eigen 1971). This principle of information generation proves just as fundamental in model and theory development in the border region between information transformation and generation in the ontogenesis (Fuchs-Kittowski, Rosenthal 1998) of living organisms. But this principle of information generation proves just as fundamental to understand the common features and qualitative differences between computer (software) and human mind as well as information systems and social organization (Fuchs-Kittowski, Heinrich, Rolf 1999).

Therefore it is important that semiotics investigate the signs and the processes in which these aspects are involved. Semiotics recognizes that in complex systems these processes give rise to meanings. This rise of meanings has to be regarded as central for the emergence of information.

It is that function can be implemented only on the basis of a special structure which is organized by information, while information acquires its meaning via its effect (function or behaviour). Structure is only created and preserved by the special function. This connection between structure and function is mediated by meanings which are formed only in this interaction process. Hence information emerges only if an evaluation has taken place by implementing the function - by the effect. 


\section{Is there a genetic determinism?}

Other epistemological and methodological statements concern the so called "genetic determinism". Is there a genetic determinism? Yes and No! The correct answer is: There is a genetic determinism only insofar as structure and function of all proteins are determined by the genes. But how proteins and cell organelles, how cells and tissue interact in ontogenesis, is brought about by further (secondary) information systems, for instance messenger substances, cell contacts (Ellersdorfer 1998). Consequently, there is not only the DNA as information source - in the process of ontogenesis the sources of cellular information join it. We clearly refute a genetic determinism that considers the genetic information, the DNA or the genes as the only source for information and control of all processes of life. We stress here (see Rosenthal 2002) that even an experienced molecular biologist cannot recognize a chicken from its DNA. He will not be able to recognize it from the DNA, because, as we have said, further information sources control the development of the organism and its life processes, even the DNA in its functioning exists only by feedbacks with specific proteins (Fuchs-Kittowski, Rosenthal 1998a and 1998b). But there is a hierarchy of the DNA, for the proteins, otherwise the network would be a chaos (Fuchs-Kittowski 1976). In an unreflected view of ontogenesis the ontogenetic process is seen as fully determined by the genome. There is only an information transformation from the genome to the adult organism. "From a semiotic view of ontogenesis", J. Hoffmeyer wrote, "the genome is seen as a set of signs" (Hoffmeyer 1992, S. 107), to be interpreted by the different, interacting structures. Genetic Information is not identical with the DNA-structure, its syntactic carrier. A semiotic view of information is a prerequisite for an understanding of the process of information generation in the process of self-organization of living systems (Hofkirchner 1998, Jahn 1998).

\section{$4 \quad$ Tailored medications}

We turn to the concrete results of the human genome deciphering and their possible ambivalent consequences as well as to the chances and risks. By knowing the most important human genes and by the further elucidation of the function of the proteins coded by them, a rational approach to new and more effective therapeutic means will be possible. All medications utilized now are actually based on approximately 400 different targets. In the proceeding of further research this number will increase by an order of magnitude. By knowing the most important human genes and the proteins coded by them, the development of more effective therapeutics will be possible. There is no identical genetic structure for all humans. Every human has an individual DNA structure regarding that approximately one percent of the three billion base pairs of the human genome, locations, may be polymorphous. Probably about approximately 150.000 of these polymorphous base pairs have the potential to change the function of a protein. According to that, the individual pattern of these 150.000 polymorphisms determines the genetic individuality of every human and the geneticly distinctive marks of ethnic groups, respectively. By knowing individual sequences or genes, tailored medications will be produced. It is possible to eliminate far reaching side effects. On the foundations of this innovative knowledge about the genesis of cancer and of degenerative diseases as well as about aging processes, there will be highly effective and safe diagnostics and therapeutics up to methods of (somatic) gene therapy. The semiotic and ethical aspects of therapeutic genetic engineering - "as editing a text of a disease", have already been discussed by E. Baer (1992) at the conference on Biosemiotics in 1992.

\section{New medicine - high costs, increase of life expectancy}

Newly developed individualized or group-specific medications will be possible, whereby the mass production in the pharmacological industry decreases. By that, a significant increasing of life expectancy with higher quality of life is to be expected for those who can benefit from this "new medicine" by owing to their material situation or a solidaric society. How will the society react to this? Because of the costs of the new medicine that will also increase, the question of funding and insuring will be of enormous importance. Up to now, this problem has been hardly discussed. 
From the life expectation statistics of a number of European and other countries during the last centuries, we can easily infer that life expectancy increases strongly, almost without any exception. In fact, it is uncertain how this development will continue; but because of the enormous jump upward that this curve shows in the $20^{\text {th }}$ century, we can take it for sure that also in the future medical innovations will have similar consequences. This time the concern is not only as to diagnostics, therapy and prophylaxis of diseases with a view to new methods and approaches, but also as to the process of aging itself. Hence, it is to be expected that this latter process can be found in our genes, due to accidental mutations in the DNA of somatic cells or to particular genes, which control aging by some until now unknown mechanism. That this may be indeed the case is shown by recent research on insects and other invertebrates. In several cases, it was possible to show that as compared to simple animal organisms a particular gene in a transmuted state did actually prolong the life of the individuals significantly.

Even if research performed with mammals or humans shows new ways to prolong life worth living, this will surely not mean eternal life. But an increase of life expectancy up to some years or even a decade has to be reckoned with, and this will lead to new social problems. With what will we be confronted in the end? Again, this is not sufficiently discussed in public.

\section{Concerning the handling of genetic data - how do we handle our own genetic structure?}

Problems are arising then, which, until now, are rarely mirrored in data protection law: How is medical confidentiality of non-medical persons reflected in DNA analysis and evaluation laid down by law?

The particular aspect is here that it is impossible to publish the results. To do this would require several volumes of the journal "Nature". Because of that, it is only possible to put it at disposal electronically, stored in data banks.

Any person, if he/she wishes, should have the right to look at his genetic factors. This looking into dispositions or predispositions can be restricted to one or a few genes and thereby remain local. But up to date, gene chips will allow including the individual factors completely. The question is: Is a data protection in the field of medical genetics achievable at all today, and if yes, who shall have access to the data?

On the one hand, the utilization of results from molecular genetics provides the possibility to see potential dangers for individuals (cancer risks, risk of degenerative diseases and other risks). But as actual examples connected with becoming, for example, a civil servant show, one is not allowed to urge people to a gene test. In Germany, a person who wants to become a civil servant has perhaps to undergo a gene test (Trautfetter 2003). Even if the person concerned does not wish to know the result directly, he/she can recognize it from the reaction of the office in charge, and in particular cases gather it as a kind of death sentence. 


\section{On the handling of genetic data \\ Not in accordance with the modalities to become a civil servant.}

Hostage of the own genes

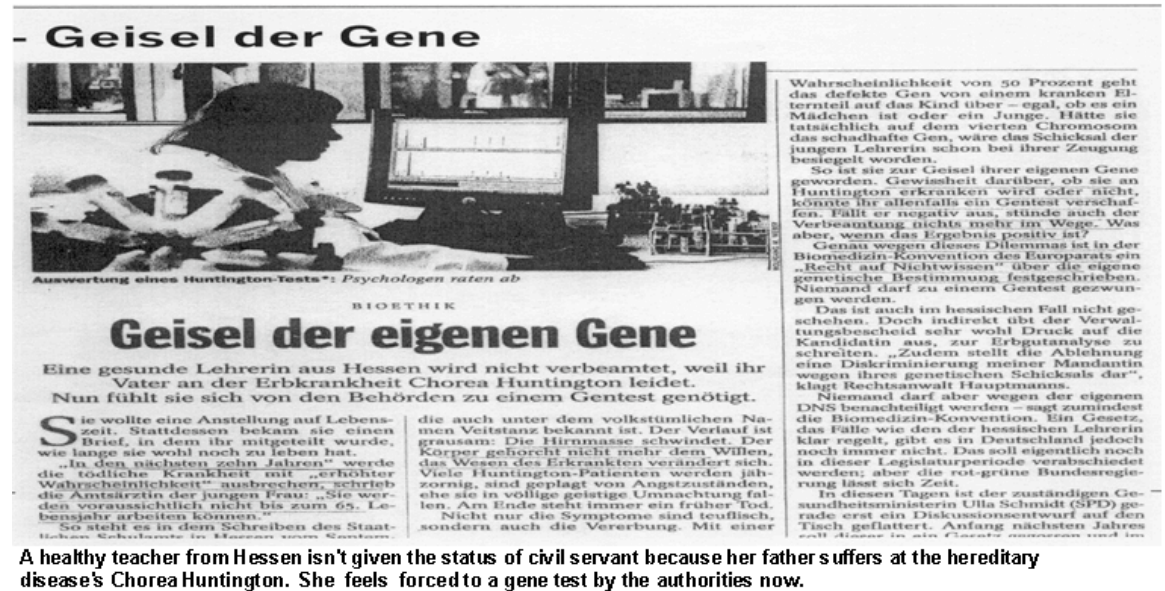

Figure 2

The example shows that the problematic point is of highest actuality, if personal data become accessible to unauthorized persons, if information on genetic dispositions are passed on to employers and insurances. Hence, in terms of the Biomedicine Convention of the European Council a "Right not to know" the own genetic determination was actually formulated. How do we cope with our new insight into our own body? The resolution of the European Parliament regarding the ethical and juridical problems of gene manipulation starts from the right to complete knowledge, but also non-knowledge of the information about the person concerned. Hopefully, the European recommendations will soon become a law in force (Bundesrepublik Drucksache 217/89: 4).

In future, the knowledge of individuals about their genetic factors, which are the causes for particular strength as well as weakness, will require a higher level of education in order to being able to cope with the interpretation and determination of the prophylactic and therapeutic measures taken that follow from the genetic results. This also requires a higher level of teaching. Also, a new foundation should be defined as to the professional education of physicians.

Legislation, jurisprudence and education have to follow suit and face new requirements.

\section{Education to anti-racism}

There are genetic differences among ethnical groups which, however, have nothing to do with the essence of being human - with the "Menschsein". Furthermore, there are no "cultural genes", in fact. But in particular genes and groups of genes we will find mutations and combinations of polymorphisms which are at the roots of physiological-chemical differences in the metabolism of individuals and ethical groups. Frequently, particular diseases appear in particular groups only. Moreover, there are many examples which prove that in particular ethnical groups, because of gene mutations, particular enzymes (for instance the alcoholhydrogenase) function better or worse so that as a consequence a better or worse digestion of, for example, alcohol is the result. That many people react by order of magnitudes differently to medications is mainly due to mutations in Cytochrom-P450-genes which in turn interact with most medications in a different way, not only in individuals, but also in whole ethnical groups.

In any case, education towards humanity is advisable. Human races and racism shall be our concern. In the past we and other authors pointed out that there are no scientific foundations for racism. But without 
leaving this position, it must be said, as we have done previously, that the more exact investigation of the human genome will show specific differences between the DNA sequences of ethnical groups, which are connected with their environment and the physiological particularities of the group. It is to be feared that proponents of racism will abuse such facts as "proofs" for the inferiority of single races asserted by them (Müller-Hill 2001). Because of that we consider it a decisive task, especially of national education, to make clear the unscientific intentions of racism.

Hence, it follows that to be of humankind is a quality that concerns an expression of character marks and value concepts which are not actually controlled by genes, and that the genetic particularities of ethnical groups do not concern mind and character. Also in connection with moral behaviour and cultural achievements, for instance concerning the talents for such achievements, biological foundations should also be taken into consideration. But it is impossible to consider moral behaviour or cultural achievements as caused by genetic constellations of humans. To the apologetics of such considerations we have to reply that they either do not know what ethics is or lack the knowledge of what genes are - perhaps they do not know enough about both (Fuchs-Kittowski, Fuchs-Kittowski, Rosenthal 1983).

In any case, education towards humanity is advisable. Besides the scientific aspects of a normal education policy, the humanistic aspects have to be considered more strongly.

\section{How do we handle our own genetic structure?}

How do we cope with our new insight into our own body?

The resolution of the European Parliament regarding the ethical and juridical problems of gene manipulation starts from the right to complete knowledge, but also non-knowledge, of the genetic information about the person concerned. It is consequently possible to demand not to be informed, not to burden one's own life in future.

Computer science and the institutions for data protection and security have to care for the sensitive administration and processing of the data stored in data banks. The far reaching automated analysis of the DNA of probands results in data, which will be stored in a databank. Up to this moment, the results are not available and in fact not interpretable. But one day that will be the case; then the investigator, respectively the specialist, can call up the stored sequences and compare them with the consensus sequences, which were generated in the internet from, for instance, the human genome project or a special laboratory data bank derived from the former respectively.

It has to be guaranteed though that the proband data do not come into unauthorized hands eventually, by networking of the different computer systems. Computer science and medicine are equally responsible for the technical and organizational part of this kind of securing secrecy.

Furthermore, it should be said that the results obtained do not necessarily refer to one person only, but also to the relatives.

We notice therefore that there should be no general obligation to present genetic data to insurance companies, employers and offices, and to consider it as an abuse, if, for instance, health insurances try to get access to genetic data in order to be able to calculate the risk of the persons insured by knowing of their genetic dispositions. With regard to that, the proportionally rare monogenic hereditary diseases, but certainly the far spread polygene dispositions may play a role, from which, out of the DNA sequence, particular diseases or negative reactions to environmental influences can be made recognizable. The insurance company may be tempted to provide for the exclusion or ask for higher fees. This should be excluded in 
any case. At this place, we would like to stress that the individual destiny of a human must not influence his insurance situation. Such non-use of something what is realizable might become a real touchstone for democracy and humanism.

Will the solidary community carry the costs of all individual dispositions, or will everybody pay for his own genes? According to our viewpoint, in its statement, the Enquête Commission "Chance and risks of genetic engineering" of Schleswig-Holstein correctly recognizes the danger, that opposed to the "basic idea of insurance, i.e. to cover individual risks by charges of the collective", it could come to a re-individualization of health risks. Even in the past, if symptoms of a hereditary disease appeared in a family, medical care was not only provided to the ones immediately concerned, but to the other members of the family, too.

By the knowledge of genetic dispositions for such diseases from the DNA-sequences, already before their clinical manifestation, the question arises as to the obligations of the physician concerning the hiding or the providing of information to the persons concerned. A patient himself/herself is also confronted with this same problem.

With the view to the developments outlined and related social requirements the question arises, whether there is a new psychology which deals with the handling of the genetic data of human individuals. How will we cope with this look into our body? Would we like to know at all what we can know now? Only now do we bite into a new apple from the tree of knowledge!! Will it drive us forever out of what we did not sense at all as paradise of naivety? May the immaterial price that the individual would have to pay for the new medicine be too high? Or could the education "towards an ethics of recognition serving life" provide a life counsel? The importance of that is not to be estimated on a level which is lower than that of the new medicine itself.

The use of embryonic ce may bring new solutions for the production of new medications and therapies and safe heavily ill people. Equally, the problematic of the re-implementation will become a unique point which is to be controlled in juridical terms. From the point of view of the physician's task to prevent and to cure, the juridical questions of life and death connected with this will have to become classified internationally as being unique.

\section{Genetic engineering and reproductive medicine - the early embryo in the Petri dish}

Genetic engineering and reproductive medicine are only indirectly connected. Of course, to fulfill the wish for a child by in vitro fertilization is possible without genetic engineering. Nevertheless the discussion how to handle the in-vitro-embryos started again after deciphering the human genome. Modern reproduction medicine is developing very fast and raises as its consequences a series of fundamental ethical, moral, but also practical questions, which not each individual, but the society as a whole has to discuss and to answer. Just in time.

Should the human being as an individual and as a genus today or in future be allowed, to produce identical copies from himself/herself by somatic core transfer? Is the production of embryonic stem cells from spare embryones for the purpose of research and development of new cell therapies in principle tolerable in ethical and moral terms? A fertilized egg cell and an early embryo, do they have a right of human dignity? Do parents possess the right to implement gene tests after the in vitro fertilization in order to avoid severe genetic defects before implantation? Why do we, in Germany, accept the abortion of a foetus up to the 12th week and after that condone this same action? Where do we have to condemn the preimplementation diagnosis, in the case of severe genetic defects as a kind of selection resulting in the killing of embryos?

Patients who already have a child with a severe damage wish to know the fate of a possible second child and ask for the implementation of a genetic diagnosis from the embryo in the Petri dish. In Germany this is 
prohibited by law - it is prohibited to manipulate the embryo. But in Great Britain this is allowed. Are the British not a cultural nation? To perform a genetic analysis in case of an embryo consisting of a few cells is possible without incurring any damage. This is not taken into consideration sufficiently. Today, in Germany, a woman has to let implant the embryo in the first place and only after this is she perhaps granted an abortion. What would be also possible without any risk is, because of the present law in Germany, only possible with a risk for the woman.

This present law was established by referring to the ethically fundamental concept of human dignity. In doing so, the assumption is being put forward that the fertilized egg cell is a human being who has the whole right of human dignity. But probably the concept of human dignity is, in this case and in a series of other contexts, too much strained, as it was formulated by the well-known federal constitution judge and novel author Bernhard Schlink (2003). Indeed, according to our viewpoint, the concept of human dignity is for a few-cell embryo, if at all, only applicable in the sense of potentiality. If the continuity is taken into consideration, this few-cell embryo may become a human being then. But the discontinuity has also to be considered, hence, the concept of human dignity is overstrained, if applied to a preliminary state of human life.

The progress of genetic engineering in connection with in vitro fertilization had the consequence that gene tests with single cells of the early embryo are possible to implement without damaging the embryo. Afterwards the embryo may become implanted into the uterus. The pre-implantation diagnosis enables to select embryos with genetic damages very early, before the implantation into the uterus. As mentioned above, it is not possible to apply this method in Germany; because according to the Embryo-protection law from 1990 it is not allowed to manipulate the embryo.

Today two things are taken into consideration in the first place. First: The embryo has to be protected as born life, because already the zygote has the right of full human dignity. Second: Many opponents of preimplantation are afraid of, perhaps not completely without reason, that parents may use this method to condition their children cosmetically.

In Europe legal requirements with regard to this are not unique. So in Great Britain the PID is allowed up to an embryo age of fourteen days. In the year 2003 the German government deposed of the absolute protection of the embryo to make the research with embryonic stem cells easier. But pre-implantation diagnosis continues to be forbidden in the future too, because of the putative danger of eugenics. In Germany the refusal of a pre-implantation diagnosis is often substantiated by Christian arguments.

Within the ongoing discussion of how to handle embryos which emerges due to in vitro fertilization and about more far-reaching questions of reproduction medicine and gene medicine, the position of the church plays a great role. As Ehmke in the year 2001 stated very correctly, since ancient times the conception was put forward by famous philosophers and later on by representatives of the church that to beget and to become a human does not happen equally. Up to the end of the $19^{\text {th }}$ century the Catholic Church purported the "successive giving of a soul" and, as we suppose, changed its position towards the conception of "giving a soul simultaneously", obviously only under the impression of the significantly increasing number of interruption by physicians and laymen.

The industrialization and proletarization, the movement for the rights of women and the scientifictechnical progress had posed new questions onto the agenda.

According to pope Pius IX, even the killing of the foetus was forbidden, when in order to save the life of the mother the physicians were acting legally. Furthermore, the Catholic Church held that death-born or aborted fruits of somebody's womb, should get neither a name nor a Christian funeral and because of this 
would not receive redemption on the day of the "Last Judgement". Hence, the attitude of the church towards the "becoming of life" did not remain unchanged in the past.

In assessing these new questions, the Jewish orthodoxy refers to the Babylonian Talmud, a collection of rabbinic commentaries, interpretations and guidelines to the Pentateuch. It is stated there that God would breathe the soul into the becoming life at the fortieth day after the fathering (begetting). The Talmud, writings connected with it, and the Pentateuch are the foundation of the Hatacha (the religious law). Moreover, from rabbis of all directions without exemption it is again and again stressed that it would be the highest obligation of the physician to cure ill men and to maintain the life of the born and that this commandment had precedence over all other obligations.

The space of fourteen days for pre-implementation diagnosis and implantation into the uterus, respectively, fixed in Great Britain, remains significantly below this forty-day limit. The scientific foundation for the fourteen-day period provides the stages of embryogenesis as they are well-established meanwhile. At approximately the fourteenth day, the first nerve cells form, and the idea is that this is an essential step in becoming a human.

Now the brain death applies for the definition of the end of a human life (after long controversial discussions in parliaments).

A strong argument in favor of the impunity of an abortion after consultation by a body that is authorized is the right of the pregnant to avoid the birth of a seriously disabled or seriously ill child without chance of becoming cured, or a particular social indication of the woman. It is neither medical nor ethical to accept why this right of the woman should not be in force for her embryo in the Petri dish, but only after implantation into the uterus. According to our viewpoint, until the birth, the embryo or the foetus are part of the body of the mother and her life, and hence only the pregnant has the right to decide on this part of her life. Sometimes it was pointed out that the need and fears of a married couple that already has a seriously disabled child to get a second similarly disabled child are not smaller only because the embryo is still outside of the body of the mother. Therefore, it is by no means justifiable to annihilate this embryo only after implantation and lodging into the uterus by a complicated abortion, if it is possible to get the same result in a much simpler manner and without any danger for the health of the woman by implementing a genetic test of this ten or twelve days old many-cell pre-stage of human life; and the embryo, if it has serious genetic defects, will not be implemented into the uterus of the mother.

\section{Genetic engineering and Eugenics}

An eugenic "program" which aims at improving human traits, such as intelligence, creativity, or beauty", was apposed by E. Baer (1992), referring to the terrible misuse of eugenic in Nazi Germany, at the conference "Biosemiotic - The Semiotic Web 1991". Today, there is the danger that parents want to condition their descendents just as they like and in accordance to fashion, that they do not want to accept harmless hereditary handicaps (for instance short-sightedness) or black hair instead of fair one. Indeed, if the society does not install effective controls from the beginning on, such an inhuman, easygoing selection could spread which is not wholesome to the gene pool of humankind.

It is possible, without danger, to take out a cell from a two- or four-cell embryo. In principle, one could breed all varieties of stem cells. This is a huge potential for the treatment of degenerative diseases (as for Parkinson). In principle, after the first cell division, one of both cells can be used up therefore. The other cell easily forms a complete human being, as it were the twin.

Reproductive cloning is to be rejected. Therapeutic cloning is to be developed. In approximately half of all (theoretically thinkable) cases this may be equally easy as a self-donation of blood. But today, tomorrow 
and in future, because of fundamental considerations, we are opposed to the generation of genetically identical copies of human beings by reproductive cloning. The danger would be too great that society would be split into biological classes, in valuable and less valuable life.

On the other hand, the therapeutic cloning up to the few cell stage, in order to obtain embryonic stem cells, which are not being repelled in terms of immunology, will have a future.

\section{Gentherapy}

As result of the Human Genome Project the locus, sequence and structure of nearly all human genes are exactly known. In the case of monogenically transmitted diseases the molecular defects (mutations) in approximately thousand genes have been identified. It is to be expected that in the next years predispositioned genes in the case of complex diseases, as for instance the different kinds: Alzheimer, Diabetes, rheumatoid Arthritis, Asthma and heart and circulation will become identified increasingly. This provides us with new perspectives towards any kind of gene therapy. It has to be differentiated between somatic genetic therapy and genetic manipulation of the germ cell. Somatic genetic therapy should, if it is therapeutically beneficial for the patient (Berliner Zeitung 2003), become promoted without reservations. In any case we are opposed however to a manipulation of germ cells, because it may have unpredictable consequences for the gene pool of humankind.

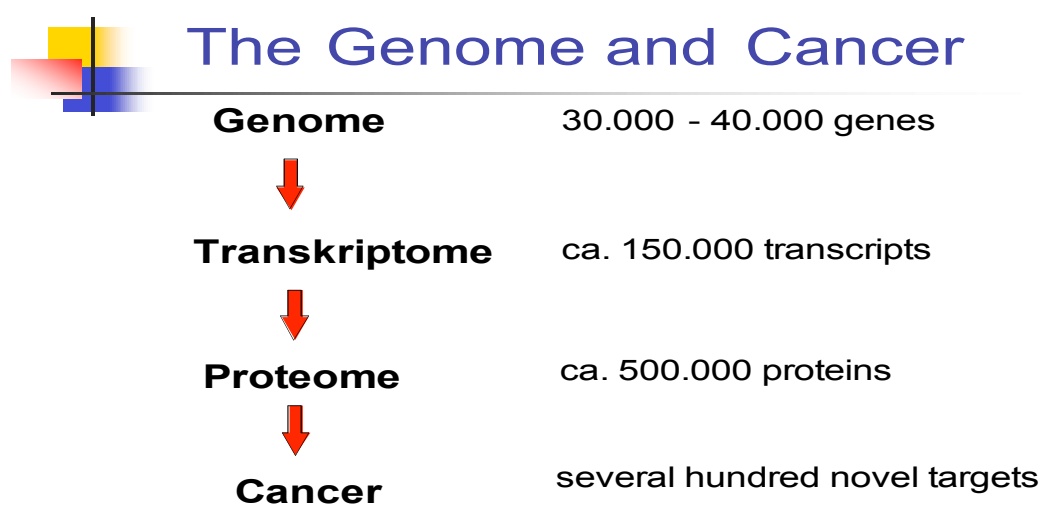

Figure 3

Already 25 years ago (Fuchs-Kittowski, Rosenthal, Rosenthal 1981), at the start of genetic-engineering, the problem of genetic manipulation of germ cells was intensively discussed. At the beginning it was partially welcomed that in future it would be possible to eliminate step by step genes which are responsible for strongest hereditary diseases or cancer. The proponents of this view do not consider that it is impossible to remove cancer genes ore other genes which are the source of hereditary diseases or other serious diseases, because in the healthy state they are necessary for life. The opponents to germ cell therapy recognized the danger that it might be possible that the elimination of such genes will have disadvantageous consequences for the gene pool of humankind. The Sickle cell anaemia is a classical example, because the Sickle cell anaemia has advantages in regions which are contaminated with malaria. Because of this we are opponents to a manipulation of germ cells.

We are and will be - unlike James Watson, who sees in the change of human genes in order to avoid diseases a meaningful therapy option and welcomed it even for cosmetic purposes (Stuttgarter Zeitung online November $8^{\text {th }}, 2003$ ) - of the strong opinion, that this genetic manipulation of human nuclei should not be carried out and should be forbidden if necessary, because of the not easily comprehensible risks. 
The possibilities of the genetic correction of somatic cells, the results of the stem cell research, and the new diagnostic methods and highly effective medicine (without or with poor side-effects), will lead in most cases to satisfying results.

\section{Humans and the Computer}

In computer science, especially in Artificial Intelligence (Al) research, as well as in gene research there is the extreme idea to improve humans, on the one hand by construction of computers that are similar to humans or will even replace humans, and on the other hand by eugenics, by the new possibilities to manipulate the human genome to achieve this end.

Because of that, it is not erroneous to ask, if such ideas will not multiply itself. False ideas get power too. So it may become dangerous, if Dan Dennet demands: "We have to free ourselves from our respect for life, if we want to make progress in artificial intelligence." (nach Weizenbaum 1977, S. 66) Benno Müller-Hill wrote, if you say again and again, that there is less-worthy life, you should not wonder when somebody is collecting tooth-gold (Müller-Hill 1981).

The present discussion on the ethical problems of genetic engineering has the consequence that the occupation with information engineering that enabled the sequencing of the human genome recedes into the background; this is what one can read on the homepage of the bioinformatics department of the University of München.

The problems of the philosophy of life and of ethics, which arise by the deciphering of human genome and by computer science that are especially promoted by the former, are hard to solve indeed. Hans Moravec talks about a post-biological age when humankind will die out and assign all human abilities to robots before. Joe Weizenbaum asks: With which speechless look a mother looks for her newborn Child. Can one transfer this to a robot?
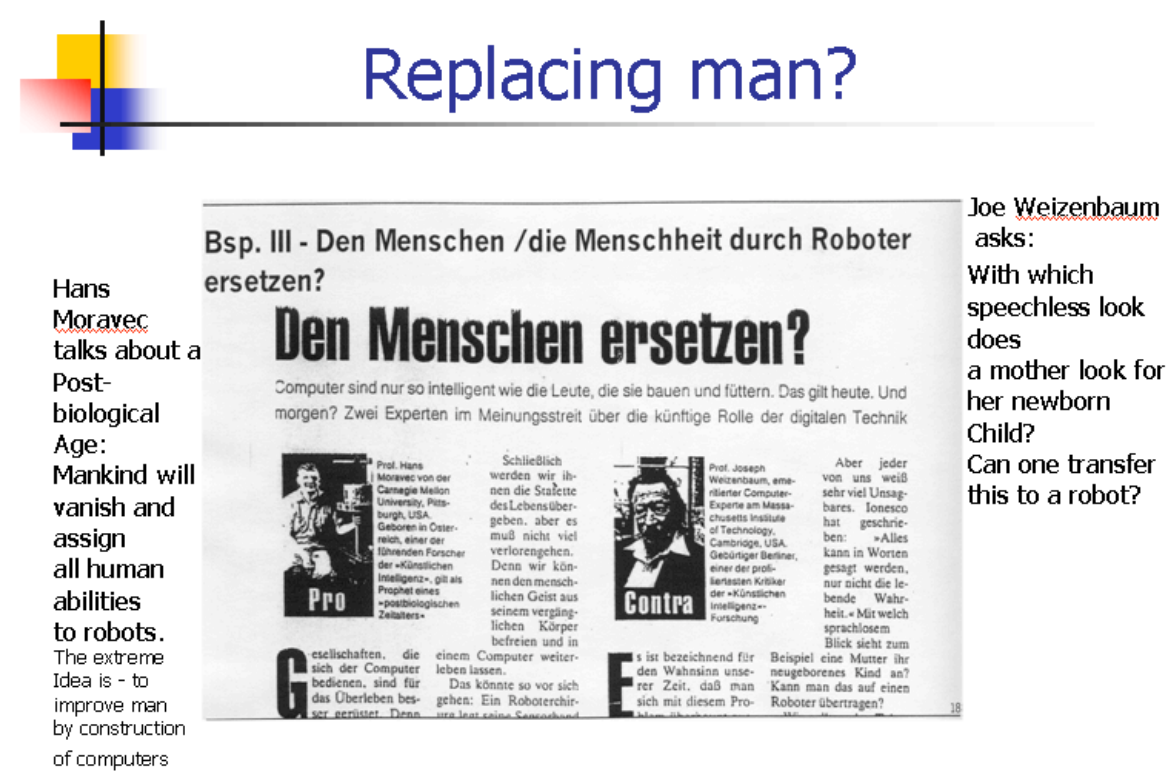

Figure 4

Within the information processing paradigm information always already exists. It is not asked how information develops, how it is generated. In nature, information generation is connected with the development of life. Information generation occurs in the phylogenesis and in the ontogenesis of living systems (FuchsKittowski et al. 1998). Information generation is also typical for developing biological and social systems. 
Living systems have a dissipative structure, they exist far from equilibrium, manifesting organization insofar as they can incorporate free energy and unload degraded by-products. Living systems are semiotic systems: They respond to their surroundings in selective ways specified by their own organization. Living systems, as self-organizing, actional systems, present also the creative power to generate new structures and functions and thus new properties, new signs and meanings, new information during their evolution. Genetic Information must not be identified with the DNA-structure, its syntactic carrier. By the unreflected view of ontogenesis the ontogenetic process is seen as fully determined by the genome, there is only an information transformation from the genome to the adult organism. To leave the role of the concrete cells and tissues out of our understanding of the developmental process, not to see processes of information generation in the ontogenetic process is a very common position. A semiotic view of information (Fleissner, Hofkirchner, Müller, Pohl, Stary 1997) is a prerequisite for an understanding of the process of information generation in the process of self-organization of living systems.

\section{References}

Baer, E. (1992) Editing the Text of a Disease: Semiotic and Ethical Aspects of Therapeutic Genetic Engineering. In: Sebeok, T., Umiker-Sbeok, J. (Eds.) Biosemiotics: The Semiotic Web 1991. New York. Mouton de Gruyter. pp 15-25.

Baer, E. (1992) Editing the Text of a Disease: Semiotic and Ethical Aspects of Therapeutic Genetic Engineering. In: Sebeok, T., Umiker-Sbeok, J. (Eds.) Biosemiotics: The Semiotic Web 1991. New York. Mouton de Gruyter. pp 15-25.

Bohr, N. (1933) Light and Life. In: Nature, 131. pp 421-457.

BR-Drs. (Bundesrepublik Drucksache) 217/89. pp 4.

Eigen, M. (1971) Selforganization of Matter and the Evolution of Biological Macromolecules. In: Naturwissenschaften, 58. pp 465-523.

Ellersdorfer, G. (1998) Epigenetische Netzwerke: Die Emergenz „zellulärer Information“ durch Selbstorganisation. In: Fenzl, N., Hofkirchner, W., Stockinger, G. (Eds.) Information und Selbstorganisation: Annäherung an eine vereinheitlichte Theorie der Information. Innsbruck. Studien-Verlag. pp 189-210.

Ellersdorfer, G. (1998) Epigenetische Netzwerke: Die Emergenz „zellulärer Information“ durch Selbstorganisation. In: Fenzl, N., Hofkirchner, W., Stockinger, G. (Eds.) Information und Selbstorganisation: Annäherung an eine vereinheitlichte Theorie der Information. Innsbruck. Studien-Verlag. pp 189-210.

Fleissner, P., Hofkirchner, W., Müller, H., Pohl, M., Stary, Ch. (1997) Der Mensch lebt nicht vom Bit allein... Frankfurt/Main. Peter Lang Verlag.

Fuchs, C., Hofkirchner, W. (2002) Ein einheitlicher Informationsbegriff für eine einheitliche Informationswissenschaft. In: Floyd, C., Fuchs, C., Hofkirchner, W. (Eds.) Stufen zur Informationsgesellschaft: Festschrift zum 65. Geburtstag von Klaus Fuchs-Kittowski. Frankfurt. Peter Lang. pp 241-281.

Fuchs-Kittowski, K. (1976) Probleme des Determinismus und der Kybernetik in der molekularen Biologie. Jena. Gustav Fischer Verlag. Fuchs-Kittowski, K. (1998) Information und Biologie: Informationsentstehung - eine neue Kategorie für eine Theorie der Biologie. In: Biochemie: ein Katalysator der Biowissenschaften, Kolloquium der Leibniz-Sozietät am 20. November 1997 anlässlich des 85. Geburtstages von Samuel Mija Rapoport, 22. pp 5-17

Fuchs-Kittowski, K., Fuchs-Kittowski, M., Rosenthal, H.A. (1983) Biologisches und Soziales im menschlichen Verhalten. In: Deutsche Zeitschrift für Philosophie, 31. pp 812- 824.

Fuchs-Kittowski, K., Heinrich, L.J, Rolf, A. (1999) Information entsteht in Organisationen in kreativen Unternehmen: wissenschaftstheoretische und methodologische Konsequenzen für die Wirtschaftsinformatik. In: Becker, König, Schütte, Wendt, Zellewski (Eds.) Wirtschaftsinformatik und Wissenschaftstheorie. Wiesbaden. Gabler Verlag. pp 330-361.

Fuchs-Kittowski, K., Rosenthal, H.A. (1998a) Eine moderne Biologie bedarf der Kategorie Information. In: Ethik und Sozialwissenschaften: Streitforum für Erwägungskultur, 9. pp 200-203.

Fuchs-Kittowski, K., Rosenthal, H.A. (1998b) Selbstorganisation, Information und Evolution: Zur Kreativität der belebten Natur. In: Fenzel, N., Hofkirchner, W., Stockinger, G. (Eds.) Information und Selbstorganisation: Annäherung an eine vereinheitlichte Theorie der Information. Innsbruck. Studien Verlag. pp 141-188.

Fuchs-Kittowski, K., Rosenthal, H.A., Rosenthal, S. (1981) Zu den modernen genetischen Technologien und dem Verhältnis von Wissenschaft und Ethik: Wahrheit und Wert, Rationalität und Humanismus. In: Geißler, E., Scheler, W. (Eds.) VII. Kühlungsborner Kolloquium: Genetic Engineering und der Mensch. Berlin. Akademie-Verlag. pp 107-129.

Fuchs-Kittowski, K., Rosenthal, H.A., Rosenthal, A. (2005) Die Entschlüsselung des Humangenoms: ambivalente Auswirkungen auf Gesellschaft und Wissenschaft. In: Erwägen - Wissen - Ethik (Deliberation Knowledge Ethics), 16. pp 149-162.

Hoffmeyer, J. (1992) Some Semiotic Aspects of the Psychophysical Relation: The Endo-Exosemiotic Boundary. In: Sebeok, T., Umiker-Sbeok, J. (Eds.) Biosemiotics: The Semiotic Web 1991. New York. Mouton de Gruyter. pp 101-123. 
Hofkirchner, W. (1998) Information und Selbstorganisation: Zwei Seiten einer Medaille. In: Fenzl, N., Hofkirchner, W., Stockinger, G. (Eds.) Information und Selbstorganisation: Annäherung an eine vereinheitlichte Theorie der Information. Innsbruck. Studien-Verlag. pp 69-95.

Jahn, R. (1998) Information und selbstreferentielle Systeme in der Ethologie. In: Fenzl, N., Hofkirchner, W., Stockinger, G. (Eds.) Information und Selbstorganisation: Annäherung an eine vereinheitlichte Theorie der Information. Innsbruck. Studien-Verlag. pp 211-252.

Müller-Hill, B. (1981) Die Philosophen und das Lebendige. Frankfurt/Main. Campus-Verlag.

Müller-Hill, B. (2001) Die Gefahr der Eugenik. Was wissen wir, wenn wir das menschliche Genom kennen?. In: Honnefelder, L., Propping, P. (Eds.) Was wissen wir, wenn wir das menschliche Genom kennen? Köln. DuMont Buchverlag. pp 218-219.

N.N. (2003) Blutkrebsfälle nach Gentherapie aufgeklärt. In: Berliner Zeitung, Nr. 242, 17.10.2003: 13.

Parthey, H. (1983) Forschungssituation interdisziplinärer Arbeit in Forschungsgruppen. In: Parthey, H., Schreiber, K. (Eds.) Interdisziplinarität in der Forschung: Analysen und Fallstudien. Berlin. Akademie-Verlag. pp 13-46.

Rosenthal, H.A. (2002) Zu einem Aspekt der genetischen Information: Geist und Materie in der frühen biologischen Evolution. In: Floyd, C., Fuchs, C., Hofkirchner, W. (Eds.) Stufen zur Informationsgesellschaft: Festschrift zum 65. Geburtstag von Klaus FuchsKittowski. Frankfurt. Peter Lang Verlag. pp 233-240.

Schlink, B. (2003) Die überforderte Menschenwürde. In: Der Spiegel, Nr. 51, Heft 1. pp 13.

Stuttgarter Zeitung 8. November 2003. http://www.stuttgarterzeitung.destz/page/detail.php/391066

The International Human Genome Sequencing Consortium (2001) In: Nature 409. pp 860.

Trautfetter, G. (2003) Geisel der eigenen Gene. In: Der Spiegel, 43. pp 216.

Weizenbaum, J. (1977) Das Menschenbild im Lichte der künstlichen Intelligenz. Prioritäten. Zürich. Pendo. 